\title{
Colon Lymphoma
}

National Cancer Institute

\section{Source}

National Cancer Institute. Colon Lymphoma. NCI Thesaurus. Code C4793.

An extranodal lymphoma that arises from the colon. The majority are B-cell non-Hodgkin lymphomas. 